\title{
Dotsenko N. METHODOLOGICAL SUPPORT FOR FORMATION OF RESOURCE REQUIREMENTS IN MULTI-PROJECT ENVIRONMENT
}

Об'єктом дослідження є прочеси управління людськими ресурсами проектів в мультипроектному середовищі. У мультипроектному середовищі рівень автономії команд в рамках організачії може бути різним, а відсутність системи контролю ресурсів на рівні портфеля знижуе ефективність управління критичними знаннями організації. Основна гіпотеза дослідження полягає в припущенні, що адекватне розуміння вимог замовника має вирішальне значення для забезпечення управління проектами, а ефективність управління людськими ресурсами в мультипроектному середовищі залежить від ефективності визначення вимог до ресурсів при формуванні команд проектів.

В ході дослідження використовуються методи системного аналізу при дослідженні процесів управління людськими ресурсами та моделюванні процесів формування вимог до команди проекту. Також використовуються компетентнісний підхід при розробиі методу формування ресурсних вимог і апарат теоріі оптимізації для формулювання та вирішення завдань формування команд проектів в мультипроектному середовищі при заданих обмеженнях.

3 метою уникнення ресурсних конфліктів запропоновано проведення аналізу вихідних даних при формуванні вимог до команди проекту. Узгодження ресурсних вимог на етапі формування команд дозволить знизити ризики виникнення ресурсних конфліктів при реалізації проектів, що входять до портфелю проектів. Розглянуто можливі результати аналізу вимог стейкхолдерів.

Запропоновано метод формування ресурсних вимог в мультипроектному середовищі, заснований на аналізі зацікавленості стейкхолдерів в процесах управління людськими ресурсами з урахуванням лояльності зачікавлених сторін, який на відміну від існуючих враховує узгодженість певних стейкхолдерами ресурсних обмежень. Це дозволить формувати узгодені вимоги до ресурсів проектів і програм.

Сформовані вимоги є вихідними даними для побудови команд проектів із застосуванням запропонованого методу формування команд в мультипроектному середовищі. Побудовано модель проиесу формування вимог до команди проекту. 3 метою автоматизації розроблено програмний комплекс, який дозволяє формувати варіанти побудови команд проекту з зазначенням характеристик варіантів, що забезпечить подальшу оптимізацію складу команди.

Ключові слова: управління проектами, вимоги до ресурсів проектів і програм, мультипроектне середовище, команда проекту, стейкхолдери проектів.

\section{Introduction}

The rapidly changing requirements of business, technology and market conditions lead to the spread of flexible methodologies for which a characteristic feature is a change in the approach to human resource management [1]. For flexible project management methodologies, it is important to ensure the autonomy of teams, issues of reservation of competencies and self-organization.

The implementation of projects in a multi-project environment puts forward additional requirements for human resource management processes: the need to attract employees to several portfolio projects, taking into account resource constraints. When forming project teams in a multi-project environment, it is necessary to take into account the resource needs of all portfolio projects.

An adequate understanding of customer requirements is critical to ensure effective project management. Since the process environment directly affects human resource management, the influence of stakeholders must be taken into account.

Thus, research aimed at solving the problem of human resource management in a multi-project environment is relevant.

\section{The object of research and its technological audit}

The object of research is human resource management processes in a multi-project environment.

The growing popularity of project portfolio management and the need to ensure project structuring has led to the development of formalization of management processes [2].

In a multi-project environment, the level of team autonomy within an organization can be different, and the lack of a resource control system at the portfolio level (control 
of critical competencies) reduces the effectiveness of critical organization knowledge management.

Changing roles and responsibilities in small teams contributes to a combination of roles, which is not always allowed by corporate or industry standards, the interests of stakeholders.

Since each project has a specific lead time, the process of forming project teams in a multi-project environment is carried out throughout the entire portfolio life cycle.

Existing approaches to the formation of teams (caselaw, competency, etc.) do not pay enough attention to the formation of requirements for teams and their coordination with project stakeholders, which leads to the emergence of resource conflicts.

\section{The aim and objectives of research}

The aim of this researchis to create methodological support for the formation of resource requirements in a multiproject environment.

To achieve this aim it is necessary to solve the following objectives:

1. To develop a method for generating resource requirements taking into account the consistency of resource constraints identified by stakeholders.

2. To build a model of the process of forming requirements for the project team.

\section{Research of existing solution of the problem}

The existing classical approach to project portfolio management does not take into account the dynamic nature of changes:

- at the project level [3];

- at the level of portfolios and programs [4, 5].

Resource management issues in terms of the project portfolio life cycle are described in [6]. The issues of balancing the complexity of project portfolios and the flexibility of their organizational units are considered in studies [7]. The proposed models provide an understanding of the management development of project companies, focusing on flexibility in a changing environment, but need to be adapted.

Team autonomy is an important principle of flexible methodologies and determines the ability of a team to determine goals, individuality, provide the necessary resources and organize itself

When analyzing the activities of teams, the following types of autonomy are distinguished:

- individual autonomy of the project team members

in carrying out their own tasks;

- internal autonomy, which is characterized by the

degree of joint decision-making in the team;

- external autonomy, taking into account the influ-

ence of the external environment of the project on

the functioning of the team [1].

For teams with a high level of autonomy, the use of self-assignment is typical in the formation of teams and the distribution of work.

Independent assignment can be defined as the ability of each team member to assign a task or user history to itself [8]. The application of this approach is possible only with a high level of corporate culture and project maturity.
The use of multi-level flexible project management makes it possible to identify the main problems of human resource management that are characteristic of flexible, self-developing teams (Table 1 ).

Multilevel flexible project management [1]

\begin{tabular}{|l|l|l|}
\hline \multicolumn{1}{|c|}{ Level } & \multicolumn{1}{|c|}{ Description } & \multicolumn{1}{c|}{ Problems } \\
\hline $\begin{array}{l}\text { Project } \\
\text { level }\end{array}$ & $\begin{array}{l}\text { Project management activi- } \\
\text { ties involving a team, chief } \\
\text { administrator (or manager) } \\
\text { and clients }\end{array}$ & $\begin{array}{l}\text { Delay or change in require- } \\
\text { ments at the project level, lack } \\
\text { af support from senior ma- } \\
\text { nagement at the project level }\end{array}$ \\
\hline $\begin{array}{l}\text { Team } \\
\text { level }\end{array}$ & $\begin{array}{l}\text { Activities involving only the } \\
\text { core development team and } \\
\text { their leader (or manager) }\end{array}$ & $\begin{array}{l}\text { Achieving cross functionality, } \\
\text { effective evaluation }\end{array}$ \\
\hline $\begin{array}{l}\text { Individual } \\
\text { level }\end{array}$ & $\begin{array}{l}\text { Activities involving individual } \\
\text { team members }\end{array}$ & $\begin{array}{l}\text { Statement of autonomy, self- } \\
\text { designation }\end{array}$ \\
\hline $\begin{array}{l}\text { Task } \\
\text { level }\end{array}$ & $\begin{array}{l}\text { Activities involving technical } \\
\text { tasks }\end{array}$ & $\begin{array}{l}\text { Lack of acceptance criteria, } \\
\text { task dependency }\end{array}$ \\
\hline
\end{tabular}

An important issue is ensuring the personnel safety of the enterprise and the development of personnel potential by increasing the loyalty and cohesion of the team [9]. Taking into account the loyalty of stakeholders in the formation of resource requirements remains an unresolved problem.

The use of outsourcing contributes to providing the company with the necessary resources, resolving resource conflicts [10]. Its effectiveness significantly depends on the specifics of the project and the industry.

In [11], the strategic role that the human resource planning (HRP) process plays in the integrated management of human resources is considered. At the stage of forecasting requirements for human resources (equirements forecasting stage), requirements are determined that take into account the interests of stakeholders, the corporate culture of the organization, the scope and specifics of the project).

Among the problems that reduce the effectiveness of human resource planning, the following are highlighted in [11]:

- lack of a strategic vision of the process;

- lack of a business expert at the personnel management specialist;

- different format of information about human resources in the organization;

- conflict between short-term and long-term needs for human resources;

- conflict between the qualitative and quantitative approaches to HRP;

- weak involvement of managers in the planning process.

The reasons for the problems considered are the lack of strategic resource planning, formalized methods and procedures for human resource planning, as well as methods for generating resource requirements.

Promising approaches in human resource management are [12]:

- use of software to search for candidates for the team and track candidates;

- preliminary assessment of the applicant to the team;

- application of the candidate management system;

- software for online interviews;

- use of artificial intelligence in the selection of personnel;

- unlocking the capabilities of passive candidates.

The use of the proposed software tools is advisable when creating an employee competency profile and selecting 
candidates for the team, but does not take into account the issues of competency reservation and resource limitations.

Thus, the analysis results allow to conclude that insufficient attention to the formation of resource requirements in a multi-project environment reduces the effectiveness of human resource management in a multi-project environment, leading to the emergence of resource conflicts.

\section{Methods of research}

The following are used in the work:

- methods of system analysis in the study of human resource management processes and modeling of the formation of requirements for the project team;

- competency-based approach in the development of a method of forming resource requirements;

- apparatus of the optimization theory for the formulation and solution of the problems of forming teams of projects in a multi-project environment under given restrictions.

\section{Research results}

The use of a stakeholder-oriented methodology for project management in a multi-project environment $[13,14]$ allows for the formation of project teams under given restrictions.

To reduce the complexity of the task of forming an adaptive project team, it is proposed to carry out a number of checks [15]:

- checking the consistency of stakeholder requirements (mutually exclusive requirements arising from the personal interests of interested parties);

- verification of compliance with the competency level of requiredapplicants;

- initial verification of reserve ratios (the ability to meet the requirements for functional reservation of critical competencies, identify the presence of critical competencies in the project, identify critical competencies in the project portfolio);

- checking for forbidden combinations (industry restrictions, corporate policy, privacy policy, privacy);

- initial analysis of the matrix of applicants (the correctness of the matrix of applicants, the presence of empty rows and columns).

The analysis of the source data during the formation of requirements for the project team will identify conflicting requirements. Coordination of resource requirements at the stage of formation of adaptive teams will reduce the risks of resource conflicts during the implementation of projects included in the portfolio of projects.
Depending on the policy of key stakeholders, various approaches to managing human resources processes can be distinguished. The classification of stakeholders by influence, power, and degree of interest allowsto distinguish subgroups of projects for which unified requirements can be formulated.

Depending on the policy of human resource management, the degree of centralization, there are various approaches to the management of human resources (Table 2).

A method for generating resource requirements is proposed, based on an analysis of stakeholder interest in human resource management processes, taking into account the loyalty of stakeholders, which, unlike existing ones, takes into account the consistency of resource restrictions defined by stakeholders. This will allow the formation of agreed requirements for the resources of projects and programs.

The method of forming resource requirements in a multiproject environment is proposed.

Stage 1. Formation of requirements for project resources: - determination of stakeholders of human resource management processes and the degree of loyalty;

- determination of resource requirements;

- determination of the profile of the project competencies;

- definition of critical competencies.

Stage 2. Checking the consistency of stakeholder requirements:

- coordination of resource allocation strategies;

- coordination of fixed resource requirements -fixed purpose (mandatory entry of certain performers into the team);

- coordination of the threshold of competencies;

- coordination of resource requirements for project operations;

- coordination of priorities for the allocation of resources between projects;

- coordination of the procedure for changing requirements.

Stage 3. Audit requirements:

- initial verification of reserve ratios;

- checking for prohibited combinations;

- initial analysis of the matrix of applicants.

Stage 4. Formation of generalized requirements for resources in a multi-project environment:

- formation of generalized resource requirements for the project;

- formation of generalized requirements for the project portfolio;

- formation of generalized requirements for critical competencies in the project;

- formation of generalized requirements for critical competencies in the project portfolio.

Analysis of approaches to human resource management

\begin{tabular}{|c|c|l|l|c|}
\hline Focus & Centralization degree & \multicolumn{1}{|c|}{ Resource pool role } & Team building & Critical competency management \\
\hline Project & Low & $\begin{array}{l}\text { Totality (amount) of project re- } \\
\text { sources }\end{array}$ & $\begin{array}{l}\text { A complete set of project teams involv- } \\
\text { ing all the resources necessary for the } \\
\text { project, the resource pool does not take } \\
\text { part in the distribution }\end{array}$ & Project level \\
\hline Portfolio & Average & $\begin{array}{l}\text { Source of resources for portfolio } \\
\text { projects. It is directly involved in } \\
\text { the formation of project teams }\end{array}$ & $\begin{array}{l}\text { Distribution (redistribution) of resour- } \\
\text { ces in a pool of resource portfolio } \\
\text { between company projects }\end{array}$ & Portfolio level \\
\hline Organization & High & $\begin{array}{l}\text { Totality of the human resources of } \\
\text { the organization }\end{array}$ & $\begin{array}{l}\text { Teams are not formed. Resources are } \\
\text { distributed according to needs }\end{array}$ & Organization level \\
\hline
\end{tabular}


Step 5. Correction of the source data.

Step 6. Monitoring changes in team requirements.

In accordance with the policy of resolving resource conflicts in the company, it is necessary to carry out certain measures in order to coordinate resource requirements. Possible results of the requirements analysis are given in Table 3.

Table 3

Possible results of stakeholder requirements analysis

\begin{tabular}{|l|l|}
\hline \multicolumn{1}{|c|}{ Result } & \multicolumn{1}{|c|}{ Description/Action } \\
\hline The source data is correct & Formation of the project team \\
\hline $\begin{array}{l}\text { Contradictory requirements } \\
\text { of stakeholders }\end{array}$ & $\begin{array}{l}\text { Coordination of stakeholder requirements by } \\
\text { means of stakeholder management tools ( } \\
\text { keholda- } \\
\text { Change project team requirements }\end{array}$ \\
\hline $\begin{array}{l}\text { Inadequate competency of } \\
\text { applicants }\end{array}$ & $\begin{array}{l}\text { Exclusion of applicants from consideration. } \\
\text { If it is impossible to form a team from the } \\
\text { remaining applicants, a change in the level of } \\
\text { required competencies is possible }\end{array}$ \\
\hline $\begin{array}{l}\text { Lack of the required number } \\
\text { of applicants to meet reser- } \\
\text { vation requirements }\end{array}$ & $\begin{array}{l}\text { lnitial analysis of the compliance of existing ap- } \\
\text { plicants with the reservation requirements (the } \\
\text { number of applicants capable of performing } \\
\text { the function is greater than or equal to the } \\
\text { reservation coefficient for this function). It is } \\
\text { necessary to review the register of applicants } \\
\text { or reduce the requirements of reservation }\end{array}$ \\
\hline Forbidden combinations & Matching analysis, requirements correction \\
\hline
\end{tabular}

If the company has the ability to hire an unlimited number of resources of the necessary qualifications, then the issue of requirements formation is reduced to the coordination of requirements between stakeholders.

In order to formalize the process of forming requirements for teams in the project portfolio, a model of the process of forming requirements for the project team has been developed (Fig. 1).
The generated requirements for the project team are the source data for building project teams. The use of methods for forming project teams in a multi-project environment [16] allowsto determine the composition of the project team that satisfy the given requirements:

- implementation of project objectives;

- competencelevel;

- reservation of functions;

- accounting for fixed appointments;

- accounting of prohibited combinations;

- maximum permissible degree of involvement in projects.

Application of the developed software package allowsto create options for building project teams indicating the characteristics of the options, which will provide further optimization of team building. If there are identical characteristics of the options for building teams, alternatives are selected according to certain criteria. When setting priorities, the criteria take into account the specifics of the project and its environment.

\section{SWOT analysis of research results}

Strengths. A method for generating resource requirements in a multi-project environment is proposed, based on an analysis of stakeholder interest in human resource management processes, taking into account the loyalty of stakeholders, which, unlike existing ones, takes into account the consistency of resource constraints defined by stakeholders. This will allow the formation of agreed requirements for the resources of projects and programs.

Since the formed requirements for the team are the initial data for building project teams, the use of agreed requirements allows to:

- determine the optimal composition of the project team according to the specified criterion, satisfying the given restrictions;

- reduce the time of formation of teams in comparison with similar methods;

- reduce the influence of the subjective factor in the management of human resources.

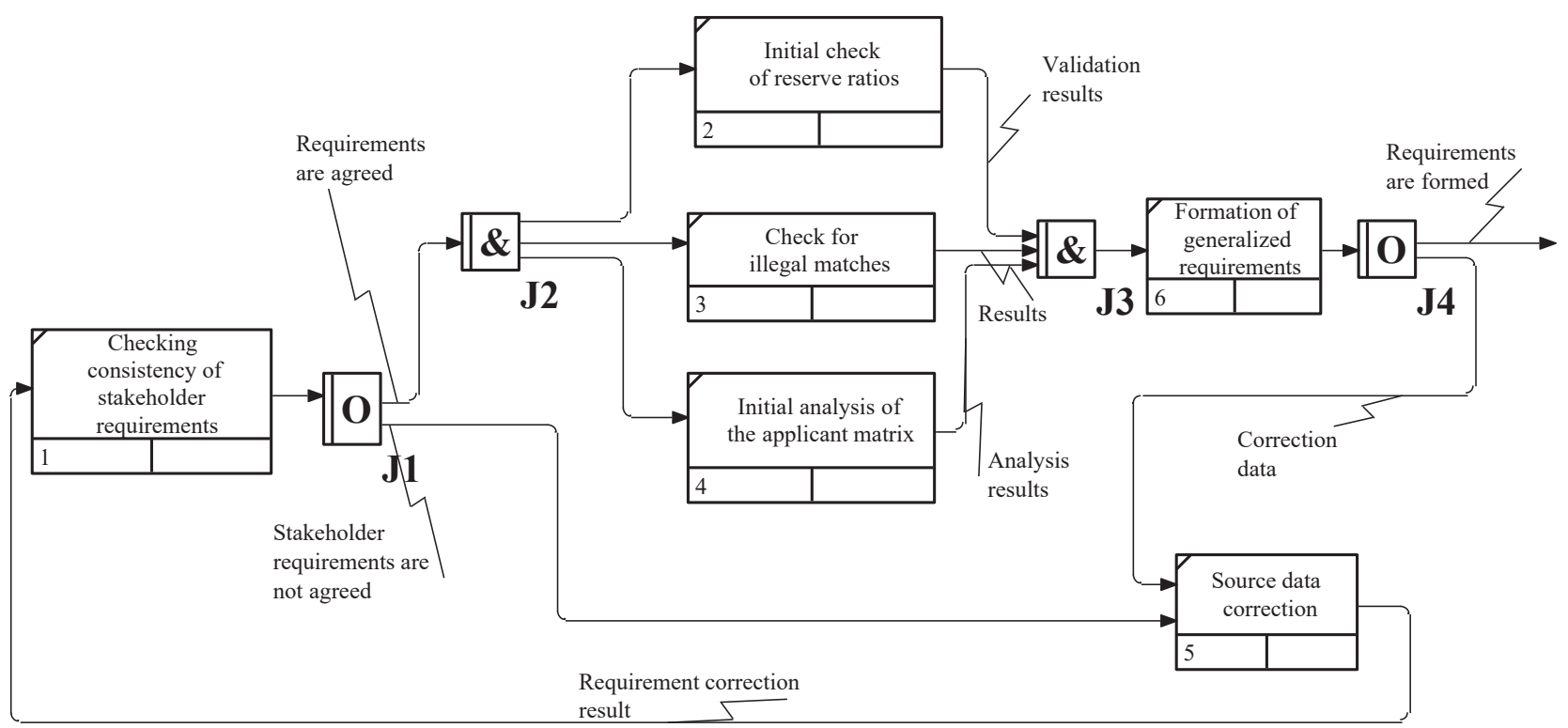

Fig. 1. Model of the process of forming requirements for the project team (IDEF 3 notation):

1 - checking the consistency of stakeholder requirements; 2 - primary check of reserve ratios; 3 - check for prohibited combinations; 4 - initial analysis of the matrix of applicants; 5 - correction of the source data; 6 - formation of generalized requirements; 0 - intersection of the «OR» type; \& - intersection of «AND» type; J1-J4 - designation of intersections 
Weaknesses. The formation of agreed resource requirements at the project planning stage requires the involvement of project stakeholders in the planning process.

Opportunities. Application of an integrated approach to human resource management in a multi-project environment, including the formation of resource requirements, building project teams, the development of resource planning information systems, will increase the viability of projects and the competitiveness of the project organization.

Treats. Lack of attention to human resource management processes in a multi-project environment, a low culture of involving stakeholders in management processes, and the lack of a conflict resolution procedure can lead to a decrease in the effectiveness of the proposed methodological support.

\section{Conclusions}

1. A method for the formation of resource requirements in a multi-project environment is proposed. Its feature is the involvement of stakeholders in the process of planning human resources at the stage of formation of resource requirements. The method of generating resource requirements in a multi-project environment contains the steps of:

- formation of requirements for project resources;

- checking the consistency of stakeholder requirements;

- audit requirements;

- formation of generalized resource requirements in

a multi-project environment;

- correction of the source data;

- monitoring changes in team requirements.

2. Simulation has been carried out and a model has been built for the process of forming requirements for the project team in IDEF3 notation. Application of the proposed model allows to formalize the process of forming resource requirements for projects in a multi-project environment.

\section{References}

1. Hoda, R., Murugesan, L. K. (2016). Multi-level agile project management challenges: A self-organizing team perspective. Journal of Systems and Software, 117, 245-257. doi: http:// doi.org/10.1016/j.jss.2016.02.049

2. Thiry, M., Deguire, M. (2007). Recent developments in projectbased organisations. International Journal of Project Management, 25 (7), 649-658. doi: http://doi.org/10.1016/j.ijproman. 2007.02 .001
3. Project Management Institute. A Guide to the Project Management Body of Knowledge (PMBOK Guide) (2017). Newtown Square: Project Management Institute, 725.

4. The standard for Program Management (2013). Project Management Institute, 176

5. The Standard for Portfolio management (2017). Newtown Square: Project Management Institute, 127.

6. Pavlov, A. N. (2015). Upravlenie portfeliami proektov na osnove standarta PMI The Standard for Portfolio Management. Izlozhenie metodologii i rekomendacii po primeneniiu. Moscow: BINOM. Laboratoriia znanii, 217.

7. Geraldi, J. G. (2008). The balance between order and chaos in multi-project firms: A conceptual model. International Journal of Project Management, 26 (4), 348-356. doi: http://doi.org/ 10.1016/j.ijproman.2007.08.013

8. Hoda, R., Noble, J., Marshall, S. (2013). Self-Organizing Roles on Agile Software Development Teams. IEEE Transactions on Software Engineering, 39 (3), 422-444. doi: http://doi.org/10.1109/ tse. 2012.30

9. Avanesova, N., Marchenko, O., Kolodyazhna, T. (2019). Modern trends in personnel safety of enterprises. Innovative Technologies and Scientific Solutions for Industries, 3 (9), 5-11. doi: http:// doi.org/10.30837/2522-9818.2019.9.005

10. Gordon, A. J. (2016). The outsourcing function for human resource projects: a path-goal theory approach International. Journal of Management and Humanities, 2.

11. Vineeth, G. (2017). The role of human resource planning in the human resource network. International Journal of Creative Research Thoughts, 23.

12. Lazarova, T. (2019). Innovationsin human resources management Journal of International Scientific Publications, 13, 215-223.

13. Dotsenko, N., Chumachenko, D., Chumachenko, I. (2019). ProjectOriented Management of Adaptive Commands Formation Resources in Multi-Project Environment. CEUR Workshop Proceedings, 2353, 911-923.

14. Dotsenko, N. V. (2016). Analiz vplyvu steikkholderiv na upravlinnia liudskymy resursamy v proekti. Informatsiini tekhnolohii ta innovatsii v ekonomitsi, upravlinni proektamy i prohramamy. Kharkiv: KhNURE, 307-315.

15. Dotsenko, N. (2019). Methodological provision of human resources management in a multi-project environment. Technology Audit and Production Reserves, 1 (2 (45)), 52-54. doi: http:// doi.org/10.15587/2312-8372.2019.160382

16. Dotsenko, N. V. (2018). Metodolohichni osnovy upravlinnia liudskymy resursamy pry hnuchkomu upravlinni v multyproektnomu seredovyshchi. Matematychni modeli ta novitni tekhnolohii upravlinnia ekonomichnymy ta tekhnichnymy systemamy. Kharkiv: FOP Panov A.M., 243-251.

Dotsenko Nataliia, PhD, Associate Professor, Department of Management, National Aerospace University H. E. Zhukovsky «Kharkiv Aviation Institute»,Ukraine, e-mail: nvdotsenko@gmail.com, ORCID: http:// orcid.org/0000-0003-3570-5900 